\title{
Prevalence and selected determinants of the risk of problem gambling among Polish secondary school students
}

\author{
Iwona Niewiadomska ${ }^{1, A, D, F \oplus}$, Lech Panasiuk ${ }^{2, E-F \oplus}{ }^{\text {, Joanna ChwaszCZ }}{ }^{1, A, C-D \oplus}$,

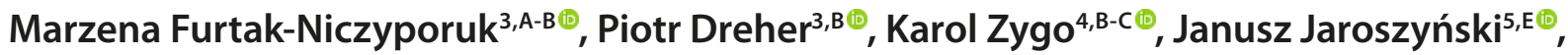 \\ Aneta Mela ${ }^{6, B-C} \odot$ \\ 1 Institute of Psychology, Faculty of Social Science, John Paul II Catholic University, Lublin, Poland \\ ${ }^{2}$ Institute of Rural Heath, Lublin, Poland \\ ${ }^{3}$ Chair and Department of Public Health, Medical University, Lublin, Poland \\ ${ }^{4}$ Chair of Public Health, Medical University, Lublin, Poland \\ ${ }^{5}$ Department of Administrative Procedure, Faculty of Law and Administration, Maria Curie-Sklodowska University, Lublin, \\ Poland \\ ${ }^{6}$ Department of Experimental and Clinical Pharmacology, Centre for Preclinical Research and Technology (CePT) Medical \\ University, Warsaw, Poland \\ A - Research concept and design, B - Collection and/or assembly of data, C - Data analysis and interpretation, \\ $D$ - Writing the article, E - Critical revision of the article, F- Final approval of article
}

\begin{abstract}
Niewiadomska I, Panasiuk L, Chwaszcz J, Furtak-Niczyporuk M, Dreher P, Zygo K, Jaroszyński J, Mela A. Prevalence and selected determinants of the risk of problem gambling among Polish secondary school students. Ann Agric Environ Med. $2020 ; 27(4)$ : $650-656$. doi: $10.26444 /$ aaem/127590
\end{abstract}

\begin{abstract}
Objective. The study had two aims. The first was to determine the prevalence of various types of gambling behaviour and the severity of gambling among secondary school students in one of the poorest provinces in Poland. The second was to identify correlations between selected socio-demographic variables and the severity of gambling problems.

Materials and method. The study was carried out on a group of teenagers from secondary schools in the Lublin Province of eastern Poland. The survey covered 923 respondents aged $17-21(M=18.06 ; S D=0.367)$. The study used a list of gambling activities, the South Oaks Gambling Screen-Revised Adolescent (SOGS-RA), and a socio-demographic questionnaire. The effects of independent variables on the severity of gambling behaviour were evaluated using the Mann-Whitney $U$ test (for binary variables, such as gender or age group) and Kruskal-Wallis one-way ANOVA for ternary variables (e.g., place of residence, type of school).

Results and Conclusions. The findings show that in the studied population $7.2 \%$ were pathological gamblers and $41.8 \%$ had not gambled during the 12 months prior to the study. These findings are consistent with the literature. There seems to be a clear trend in which pathological gambling is found most frequently among technical secondary school students, and least frequently among those from secondary schools of general education. In addition, persons who had lived (until the age of 10) in rural areas scored the lowest in SOGS-RA, while those from cities below 50,000 residents, scored the highest. In families with a gambling member, pathological gambling was found 1.7 times more frequently.
\end{abstract}

\section{Key words}

addiction, gambling, school students

\section{INTRODUCTION}

For several dozen years gambling has been described as a disorder although its definition has remained controversial among scholars interested in this phenomenon $[1,2,3,4,5$, $6,7]$. The most recent, fifth, edition of the Diagnostics and Statistical Manual of Mental Disorders - DSM-V [8] defines pathological gambling as an addiction which constitutes a profound shift in the approach to its diagnosis. Problem gambling differs from pathological gambling in terms of disorder stage, with people at earlier stages of the disorder whose behaviour does not meet the necessary criteria for pathological gambling, being referred to as problem gamblers [9]. However, the latest International Statistical Classification

Address for correspondence: Marzena Furtak-Niczyporuk, Chair and Department of Public Health, Medical University, Chodźki 1, 20-093, Lublin, Poland E-mail: marzenafurtakniczyporuk@umlub.pl

Received: 25.02.2020; accepted: 16.09.2020; first published: 28.09.2020 of Diseases and Related Health Problems (ICD-10), which is now applicable, still considers pathological gambling as one of the disorders of personality and impulse control [10]. As a result of these differences in the approach to gambling as a disorder, the diagnostic criteria for, and the definition of, gambling continue to be open for discussion.

Gambling in Poland and worldwide. Poland has been faced with a growing number of people at risk of problem or pathological gambling. A study conducted in 2011 by the Public Opinion Research Centre (CBOS) on a representative sample showed that $50 \%$ of the adult Polish population played games of chance for money [11]. In addition, a 2015 CBOS study demonstrated that approx. $2 \%$ of gamblers experienced problems due to gambling, and as many were at risk of doing so. Moreover, male gamblers proved to be more likely to develop this addiction than female gambles. In the study group, one in 5 male gamblers exhibited addiction 
symptoms, while with female gamblers this was the case half as frequently [12].

As shown in a nationwide study conducted in Poland in 2011 by the Natanaelum Association, Institute for Psychoprevention and Psychotherapy, the number of people seeking help from addiction treatment centres in relation to their excessive involvement in gambling had been growing year by year [13].

As demonstrated by Polish studies, participation in gambling games is relatively widespread among teenagers. Results of 2011 ESPAD study show that about $2 \%$ of young Poles (aged 16-19) are at risk of problem gambling [14]. Another study by CBOS in 2012, published in a report entitled 'Estimated prevalence of, and risk and protecting factors for, gambling, including problem (pathological) gambling and other behavioural addictions', reported that over the 12 months preceding the study nearly one in 4 Polish teenagers aged 15 or over had played games for money. Overall, more than 50,000 young Poles, who had gambled at least once in their lives, were addicted to gambling, and almost 200,000 more were at risk of developing the addiction [15].

Studies conducted on young gamblers aged below 20 have shown that the problem of gambling develops 6 times faster (within approx. 2 years) in teenagers than in adults. Among gamblers below 20 years of age, problem gambling is most likely to affect boys [16]. In addition, studies have shown that adolescents, and especially teenage boys, show an increased risk of developing serious problems related to, and suffering the consequences of, gambling [17]. Research into online gambling, conducted in 2007 in North America (covering both the USA and Canada), demonstrated that as many as $43 \%$ of respondents experienced problems associated with online gambling and met the criteria for problem gambling [18].

Tavares et al. (2017) conducted a nationwide study in Brazil, South America, on the prevalence of gambling among young people (aged 14 or over). The findings showed that $1 \%$ of young Brazilians were pathological gamblers and 1.3\% were problem gamblers [19].

But problem gambling is not unique to the Americas. It has been estimated that as many as $59 \%$ of people living in south-eastern Asia are problem gamblers. In addition, it has been demonstrated that factors such as gender (men) and age (young people) are more likely to entail the risk of pathological gambling. Interestingly, previous studies have also shown that gambling is the most popular entertainment of choice in China. Analysis of historical statistical data shows that the proportion of pathological gamblers in China has been steadily increasing and corresponds to $4 \%$ of its population [20].

Similar findings are reported by studies conducted in Europe. A survey carried out in 2011 by the European Gaming and Betting Association at the request of the European Parliament shows that the EU gambling sector as a whole generates about EUR 80 million in profit a year. In 2011, online gambling only yielded profits of EUR 13 million [21]. The widespread popularity of gambling activities is confirmed by studies conducted in the UK, where $68 \%$ of citizens engage in gambling [22]. Epidemiological data from Switzerland, France, and The Netherlands from 20002005 show that $3-3.3 \%$ of adult citizens of those countries are problem gamblers, and about $1.8 \%$ meet pathological gambling criteria [23]. Also, studies carried out in Italy showed that over one million students, aged 15-19, equal to $44.2 \%$ of Italian students, have problems with gambling [24].

To sum up, it can be stated a literature review shows that approximately $0.9-8.1 \%$ of adolescents and $7.2-13.3 \%$ of college students worldwide, meet the criteria for problem or pathological gambling [25].

The cited data show that gambling, and consequently, addiction to gambling, is becoming a major problem for many contemporary societies, all the more so because it affects a growing number of young people, including children. Factors that contribute to the risk of the problem of pathological gambling include the wide availability of, and simple rules for, most gambling games, as well as poor social awareness of the negative consequences of gambling. Psychological risk factors for gambling include low self-esteem, sense of loneliness, emotional immaturity, achievement-oriented mindset, desire to be the best, drive towards thrill seeking, and the desire for a sense of belonging and being accepted by peers $[26,27]$.

The literature on the subject shows that the abovementioned psychological characteristics are also an important part of adolescence. In this unique period in their lives, adolescents are confronted with a doubly difficult situation as they face developmental issues and problems posed by the globalised world they live in [28]. Young people aged 16-19 find themselves in a developmental period during which they are more likely to develop substance addictions (to alcohol, drugs, tobacco, and medicines) and behavioural addictions (Internet, TV, computer games, and gambling) $[29,30]$. A significant involvement of young people is found especially in relation to 2 types of games, namely Lotto and text-to-win SMS contests, with nearly two-fifths of all respondents declaring having participated in these. A slightly smaller popularity among young people is enjoyed by slot machines and online games, but participation in these is also considerable with figures reaching nearly one-fourth of all studied teenagers [31].

This overview of research findings reported over a span of nearly 20 years shows a growing trend in the popularity of gambling activities among young people, and suggests that this process is a long-term one.

Selected psychosocial variables associated with problem gambling. Problem behaviour associated with gambling has a number of consequences. Involvement in gambling causes social, financial, health-related, and psychological damage to the individual, family, friends and social milieu $[32,33]$.

Literature and research findings clearly show evidence of genetic determinants in involvement in gaming. Dopamine receptor D2 has been identified as increasing the likelihood of developing gambling addiction. In a study conducted on 171 gamblers, this gene was found in $51 \%$ of respondents [34]. In addition, the development of interest and continued involvement in gambling are supported by cognitive disorders, especially various cognitive distortions $[35,36]$.

Social factors associated with gambling include both growing affluence and, paradoxically, poverty. People are often encouraged to become involved in gambling through their desire to make money and become richer [37,38]. Some studies have proved the existence of correlations between gambling behaviour in children and that of their parents. Regular involvement of one parent in gambling proved to 
be linked with a threefold increase in the likelihood of risky gaming in children. However, when a parent was a pathological gambler, this likelihood increased by as much as 10 times [39]. The atmosphere at home is important, especially the lack of emotional connection, frequent quarrels, and wrong parent attitudes, such as being excessively demanding or excessively protective [38]. Family norms and values are also crucial. Unfavourable characteristics, as listed by Bellringer, include a broken home, a dysfunctional or very poor family, serious family problems, infidelity, and the attachment of excessive importance to money [38]. It is also important to note the importance of perceived social support, especially the assistance available to the individual or group in difficult, stressful or critical situations, which are difficult to overcome without support from others [37, 40].

Individual-specific factors include mainly gender and age. Studies show that men $(6 \%)$ are more likely to become addicted to gambling than women (0.5\%) [41]. In addition, it has been demonstrated that adult gambling addicts had their first gambling experiences as early as before the age of 10 [42]. The literature on the subject indicates that schoolchildren are at risk of gambling behaviour [43]. Moreover, Livingstone and Palmer confirmed that young people were more likely to suffer negative consequences associated with various behavioural addictions, including gambling [44]. A Polish study carried out by the Institute of Psychiatry and Neurology (IPiN) between 2015 - 2016, demonstrated that the highest proportion of problem gamblers and persons at risk of gambling addiction (12\%) was found among children and teenagers aged 18 or under [45].

\section{OBJECTIVE}

The study had two aims: 1) to determine the prevalence of various types of gambling behaviour, and the severity of gambling among secondary school students from one of the poorest provinces in Poland; 2) to identify correlations between selected socio-demographic variables and the severity of gambling problems. Due to the exploratory nature of the study and the unique nature of the region where the study was conducted, no detailed hypotheses were formulated.

\section{MATERIALS AND METHOD}

Participants and procedure. The study was carried out on a group of teenagers from secondary schools in the Lublin Province in eastern Poland. GDP analyses prepared by the Statistical Office of the European Union (Eurostat), show that this region is unique in that it is not only one of the poorest in Poland, but also one of the poorest in Europe. Schools were randomly selected for the study to account for the school system in Eastern Poland considering such criteria as town/ city size, type of school, and final exam pass ratio (below or above 50\%). The survey was carried out in groups during lessons by trained interviewers, following prior consent from the head teacher. Participation in the study was voluntary and anonymous.

The survey covered 923 respondents aged 17-21 ( $\mathrm{M}=18.06$; $\mathrm{SD}=0.367)$. There were slightly more female $(52 \%)$ than male respondents. A significant majority of respondents (85.4\%) declared that they had gambled at least once in their lives, and $58.1 \%$ of them had done so during the year prior to the study.

Measures. The study used a list of gambling activities, the South Oaks Gambling Screen-Revised Adolescent (SOGSRA), and a socio-demographic questionnaire. The list of gambling activities included 12 games (e.g., playing cards for money). Respondents were asked to assess how often they had played each game over the previous 12 months. They were to do this using a scale from 1 - never, to 5 - daily.

SOGS-RA is a screening tool for evaluating the level of problem gambling risk [46]. It contains one question about how often the respondent has returned on another occasion in an attempt to win back the money lost, and 11 yes-no, or polar questions (e.g., 'In the past 12 months when you were betting, have you ever told others you were winning when you really were not winning?'). Depending on the number of affirmative answers, respondents' gambling behaviour can be assigned to one of 4 categories, or levels, where Level 0 (non-gambling) means no risk and no past year gambling; Level 1 (non-problem gambling) describes people who play less often than every day and score 0 points in SOGS-RA, or play less often than once a week and score 1 point in SOGSRA; Level 2 (at-risk gambling) means playing at least once a week and scoring one point in SOGS-RA, or playing less often than once a week and scoring 2 points; Level 3 (problem gambling) corresponds to problem gambling (playing every day, or 2 affirmative answers in SOGS-RA and playing at least once a week).

A number of socio-demographic variables were also taken into consideration, such as gender, age, type of school, size of place of residence until the age of 10 , size of current place of residence, type of current place of residence, family type, atmosphere at home, family size, attitude to religion, presence of a mentor, and gambling among family members.

Data analysis. The effects of independent variables on the severity of gambling behaviour were evaluated using the Mann-Whitney $U$ test (for binary variables, such as gender or age group) and Kruskal-Wallis one-way ANOVA for ternary variables (e.g., place of residence, type of school). Factors which increased the likelihood of problem gambling were assessed using a chi-squared test, and either the Odds Ratio (binary variables) or Adjusted Standardised Residuals (ternary variables). All statistical analyses were performed using IBM SPSS Statistics v23.

Mann-Whitney $U$ test and Kruskal-Wallis one-way ANOVA are the most commonly used statistical methods in psychology or medicine, and were used in the current analysis due to simple procedure. Multifactor analysis was used to evaluate dependent variables, from which odds ratios were derived.

\section{RESULTS}

Respondents usually engaged in such forms of gambling as lotto or other lotteries, scratch lotteries, slot machines, and playing cards for money (Tab. 1). They were relatively less likely to play bingo for money, bet on animals, or play the market. 
Table 1. Types and frequency of gambling activities undertaken by respondents

\begin{tabular}{lc}
\hline Form of gambling & Median \\
\hline Lotto, cash lotteries or other lotteries & 1.95 \\
\hline Scratch lotteries and 'paper-based' games other than lotteries & 1.84 \\
\hline $\begin{array}{l}\text { Slot machines, poker machines or other machines for playing games } \\
\text { for money }\end{array}$ & 1.40 \\
\hline Playing cards for money & 1.37 \\
\hline Sports betting (e.g., through a bookmaker or online) & 1.22 \\
\hline Playing bows, billiards, golf or other games of skill for money & 1.16 \\
\hline Playing games for money online (e.g., poker, roulette) & 1.12 \\
\hline Playing dice for money & 1.09 \\
\hline Playing in a casino (legal or illegal) & 1.09 \\
\hline Playing the market (e.g., investing in options or on the commodities & 1.08 \\
\hline $\begin{array}{l}\text { market) } \\
\text { thetting on horse or dog racing, or betting on other animals (e.g., on }\end{array}$ & 1.06 \\
\hline \begin{tabular}{l} 
Playing bingo for money \\
\hline
\end{tabular} & 1.06 \\
\hline
\end{tabular}

The studied population was dominated by non-problem gambling (45.3\%) and non-gambling (41.9\%) groups (Tab. 2). Those with the most serious gambling problems accounted for $7.2 \%$ of all respondents, and at-risk gamblers $-5.6 \%$.

Table 2. Prevalence of each gambling risk level

\begin{tabular}{lccc}
\hline SOGS (levels) & No. & $\%$ & Cumulative percent \\
\hline General Physical & 386 & 41.8 & 41.9 \\
\hline Cardiopulmonary & 418 & 45.3 & 87.2 \\
\hline Gastrointestinal & 52 & 5.6 & 92.8 \\
\hline Neurological & 66 & 7.2 & 100.0 \\
\hline
\end{tabular}

Analysis of socio-demographic variables moderating gambling risk levels among Polish teenagers (Levels 0-3) showed the existence of significant differences in relation to gender, type of school, place of residence until the age of 10, and gamblers in the family (Tab. 3). Gambling was found to be more popular among male than among female respondents. The highest prevalence of gambling behaviour was found in secondary schools of general education, while the lowest in technical secondary schools. The greatest gambling problems were observed among respondents from the largest cities. However, only the place of residence until the age of 10 proved significant in this respect. Another variable that substantially contributed to gambling was the presence of a gambler in the family.

Analysis of the prevalence of problem gambling (PG) in the study group indicated 2 factors which significantly increased the likelihood of PG (Tab. 4). The first factor was gender, with males being 7 times more likely than females to be at-risk problem gamblers. The second factor was having an active gambler in the family. Such gambling family members increased the likelihood of PG among Polish students by 1.7 times. Other demographic variables examined during the study proved insignificant in terms of moderating the prevalence of PG risk.

\section{DISCUSSION}

The above-mentioned findings show that in the studied population $7.2 \%$ were pathological gamblers and $41.8 \%$ had not gambled during the 12 months prior to the study. These findings are consistent with the literature. Pietrzak et al. estimated that in the USA about $20 \%$ of young people were problem gamblers. A survey carried out since 1995 showed that approx. $14 \%$ of adolescents were problem gamblers, and about $7 \%$ of studied teenagers showed serious problems related to their gambling which could be described as pathological [47].

Pathological gambling was found 6.8 times more frequently in males than in females. In addition, males obtained higher scores in SOGS-RA than women. The current findings are consistent with trends emerging from the literature on the subject - a CBOS study conducted in 2015 showed that male gamblers were more likely to develop this addiction than female gamblers. In the study group, one in 5 male gamblers exhibited addiction symptoms, while with female gamblers this was the case half as frequently[12].

Students from technical secondary schools and vocational schools scored higher in SOGS-RA than those from secondary schools of general education. There seems to be a clear trend where pathological gambling is found most frequently among technical secondary school students, and least frequently among those from secondary schools of general education.

In addition, persons who had lived (until the age of 10) in rural areas scored the lowest in SOGS-RA, while those from cities with less than 50,000 residents scored the highest. Data from the Victorian Gambling Study (VGS) and Victorian Longitudinal Attitudes Survey in Austria show that people living in metropolitan areas are characterised by increased rates of gambling problems and risk behaviour. The data show that in such areas gambling is more accessible, and, consequently, easier to engage in [48].

People who have a gambler in their family scored higher (in SOGS-RA) than those who did not. In families with a gambling member, pathological gambling was found 1.7 times more frequently. There is a correlation between gambling behaviour in children and that of their parents. Regular involvement of one parent in gambling has been linked with a threefold increase in the likelihood of risky gaming in children. When a parent is a pathological gambler, this likelihood increases by as much as 10 times [39].

No correlation was found between gambling and such variables as age (trend $=0.096$ ), current place of residence (and type of housing: family house/privately rented room or apartment/dormitory), family size (small/large), atmosphere at home, family type (complete/single-parent), attitude to religion, or presence of a mentor.

\section{CONCLUSION}

The phenomenon of youth gambling as an emerging field of research has received increasing attention in the past 3 decades. Echoing the recommendation by Derevensky [17], it is suggested that greater attention should be paid to the study of youth gambling. It is to be hoped that the presented study will increase understanding of youth gambling when planning treatment for problem gambling and addiction, and attract more attention from researchers to conduct further studies in this field. 
Table 3. Demographic data and SOGS scores

\begin{tabular}{|c|c|c|c|c|c|}
\hline & \multirow{2}{*}{ No. } & \multirow{2}{*}{ Proportion (\%) } & \multirow{2}{*}{$\frac{\text { SOGS Level Score }}{\text { Median }}$} & \multirow{2}{*}{ test } & \multirow{2}{*}{$\mathrm{p}$} \\
\hline & & & & & \\
\hline Gender & & & & 8.778 & 0.001 \\
\hline Female & 480 & 52.0 & .4912 & & \\
\hline Male & 443 & 48.0 & .8966 & & \\
\hline School type & & & & 9.767 & 0.008 \\
\hline Secondary school of general education & 525 & 56.9 & .6076 & & \\
\hline Technical secondary school & 325 & 35.2 & .7640 & & \\
\hline Vocational school & 73 & 7.9 & .6984 & & \\
\hline Age & & & & 1.666 & 0.096 \\
\hline $17-18$ & 848 & 91.9 & .6555 & & \\
\hline $19-$ & 75 & 8.1 & .8033 & & \\
\hline Place of residence until the age of 10 & & & & 6.296 & 0.043 \\
\hline Rural area & 526 & 59.1 & 6411 & & \\
\hline City with up to 50,000 residents & 183 & 20.6 & .6358 & & \\
\hline City with more than 50,000 residents & 181 & 20.3 & .7848 & & \\
\hline Current place of residence & & & & 3.530 & 0.171 \\
\hline Rural area & 524 & 57.1 & 6469 & & \\
\hline City with up to 50,000 residents & 186 & 20.3 & 6347 & & \\
\hline City with more than 50,000 residents & 207 & 22.6 & .7500 & & \\
\hline Type of housing & & & & 0.347 & 0.841 \\
\hline Family house & 826 & 90.7 & .6589 & & \\
\hline Dormitory & 57 & 6.3 & .7174 & & \\
\hline Privately rented room or apartment & 28 & 3.1 & .6522 & & \\
\hline Family type & & & & .203 & 0.839 \\
\hline Complete & 767 & 84.1 & 6697 & & \\
\hline Single-parent & 145 & 15.9 & .6563 & & \\
\hline Atmosphere at home & & & & 3.901 & 0.142 \\
\hline Parents are very friendly towards each other & 303 & 32.8 & .6222 & & \\
\hline Parents generally get along & 432 & 46.8 & .7170 & & \\
\hline Parents frequently quarrel & 88 & 9.5 & .6076 & & \\
\hline Family size & & & & 0.066 & 0.947 \\
\hline $2+1$ or smaller & 444 & 48.6 & 6615 & & \\
\hline $2+2$ or bigger & 470 & 51.4 & .6658 & & \\
\hline Attitude to religion & & & & 2.830 & 0.419 \\
\hline Religious & 570 & 62.0 & .6413 & & \\
\hline Neutral/Lapsed & 117 & 12.7 & .7660 & & \\
\hline Spiritual non-religious & 150 & 16.3 & .6838 & & \\
\hline Non-religious/Agnostic/Atheist & 82 & 8.9 & .6667 & & \\
\hline Presence of a mentor & & & & 0.295 & 0.768 \\
\hline No & 512 & 56.0 & .6570 & & \\
\hline Yes & 402 & 44.0 & .6686 & & \\
\hline Gambling family member(s) & & & & 3.145 & 0.002 \\
\hline No & 674 & 73.0 & .6242 & & \\
\hline Yes & 249 & 27.0 & .7885 & & \\
\hline
\end{tabular}


Table 4. Prevalence of pathological gambling (PG)

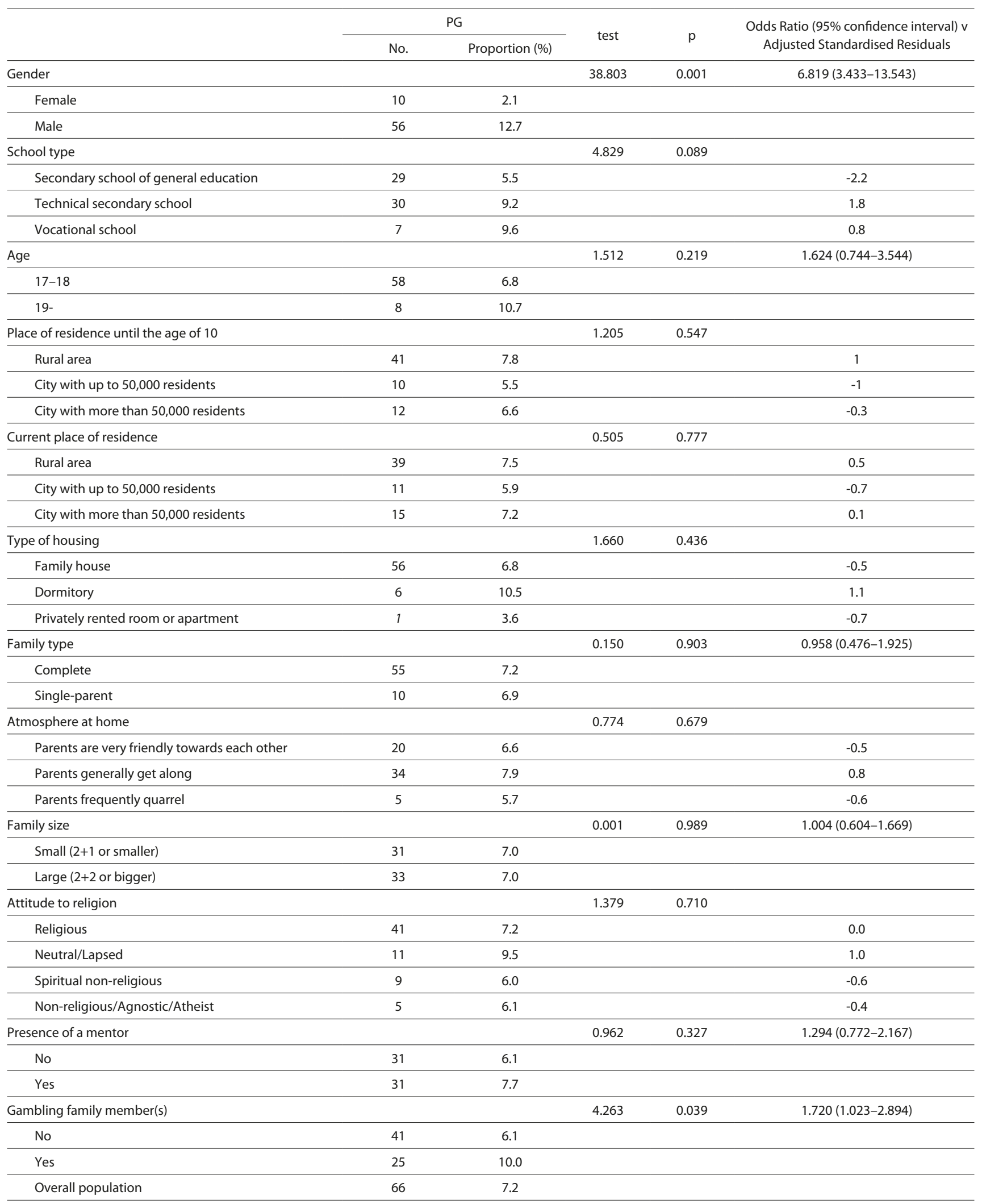




\section{REFERENCES}

1. Blaszczynski A. Pathways to Pathological Gambling: Identifying Typologies. J Gambling Issues. 2000. doi: 10.4309/jgi.2000.1.1

2. Griffiths M. Online Gambling Addiction: the Relationship Between Internet Gambling and Disordered Gambling. Gdańsk: Gdańskie Wydawnictwo Psychologiczne. Current Addiction Reports. 2015; 2: 185-193.

3. Williams RJ, Volberg RA, Stevens RMG, Williams LA, Arthur JN. The Definition, Dimensionalization, and Assessment of Gambling Participation. Report prepared for the Canadian Consortium for Gambling Research. 2017; February 1.

4. Cisneros Örnberg J, Tammi T. Gambling as a public health problem: Safeguarding the monopolies in Finland and Sweden. J Gambling Issues. 2013;26.

5. Hing N, Nuske E, Gainsbury S, Russell A, Breen H. How does the stigma of problem gambling influence help-seeking, treatment and recovery? A view from the counselling sector. Int Gambling Studies. 2016; 16(2): 263-280.

6. Langham E, Thorne H, Browne M, Donaldson P, Rose J, Rockloff $M$. Understanding gambling related harm: a proposed definition, conceptual framework, and taxonomy of harms. BMC Public Health. 2016; 16(1): 1 .

7. Puig, A, Vilanou C. Substance abuse treatment. Generalities specificities. 2012: 38-46.

8. American Psychiatric Association. Diagnostic and statistical manual of mental disorders (5th ed.). Washington, DC: Author. 2013.

9. Lupi M, Martinotti G, Acciavatti T, Pettorruso M, Brunetti M, Santacroce R, et al. Pharmacological treatments in gambling disorder: a qualitative review. BioMed Res Int. 2014: 1-7.

10. World Health Organization. The international classification of diseases and related health problems (10th Revision). Geneva: Author. 1992.

11. Gwiazda M. Polak w szponach hazardu [Polish people in the grip of gambling]. Warsaw: CBOS. 2011

12. Bador B, Gwiazda M, Hermann M, Kalka J, Moskalewicz J. Oszacowanie rozpowszechnienia wybranych uzależnień behawioralnych oraz analiza korelacji pomiędzy występowaniem uzależnień behawioralnych a używaniem substancji psychoaktywnych [Estimated prevalence of selected behavioural addictions and assessment of correlations between behavioural addictions and psychoactive substance use]. Warsaw: CBOS. 2015

13. Lelonek-Kuleta B, Chwaszcz J. Raport z badań w ramach zadania "Przeprowadzenie badania majacego na celu zdiagnozowanie zasobów instytucjonalnych i osobowych z zakresu profilaktyki i udzielania pomocy w zakresie uzależnień behawioralnych, w tym hazardu problemowego/patologicznego w Polsce [A report from a study conducted as part of a project entitled "A study designed to assess institutional and individual resources related to prevention and assistance in relation to behavioural addictions, including problem/pathological gambling in Poland"]. Lublin: Stowarzyszenie Natanaelum. 2011.

14. Sierosławski J. Używanie alkoholu i narkotyków przez młodzież szkolną. Raport z ogólnopolskich badań ankietowych zrealizowanych w $2011 \mathrm{r}$. Europejski program badań ankietowych w szkołach ESPAD [Alcohol and drug use among schoolchildren. A report from a nationwide survey carried out in Poland in 2015. European School Survey Project on Alcohol and Other Drugs, ESPAD]. Warsaw. 2015

15. Badora B, Gwiazda M, Hermann M, Kalka J, Moskalewicz J. Oszacowanie rozpowszechnienia oraz identyfikacja czynników ryzyka i czynników chroniących w odniesieniu do hazardu, w tym hazardu problemowego (patologicznego) oraz innych uzależnień behawioralnych [Estimated prevalence of, and risk and protecting factors for, gambling, including problem (pathological) gambling and other behavioural addictions]. Warsaw: CBOS. 2012

16. Carneiro E, Tavares H, Sanches M, Pinsky I, Caetano R, Zaleski M, Laranjeira R. Gambling onset and progression in a sample of at-risk gamblers from the general population. Psychiatry Res. 2014; 216(3) 404-411.

17. Derevensky JL, Gilbeau L. Adolescent Gambling: Twenty-five Years of Research. Can J Addiction. 2015; 6(2): 4-12.

18. Hing N, Russell AM, Browne M. Risk Factors for Gambling Problems on Online Electronic Gaming Machines, Race Betting and Sporsta Betting. Frontiers in Psychology. 2017; 8: 779.

19. Medeiros G, Grant J, Tavares H. Gambling disorder due to Brazilian animal game ("Jogo do bicho") gambling behavior and psychopatology. J Gambling Studies. 2017; 32: 231-241.

20. Oei Po T, Gog Z. Interactions Between Risk and Protective Factors on Problem Gambling in Asia. J Gambling Studies. 2013; 31(2).

21. Pop V. Gambling in the EU: A long way from harmonised rules. 2014 https://euobserver.com/economic/123649

22. Bowden-Jones H, George S. A Clinician's Guide to Working with Problem Gamblers. London and New York: Routledge. 2015.

23. Pfund RA, Whelan JP, Peter SC, Meyers AW. Can a Motivational Letter Increase Attendance to Psychological Treatmentfor Gambling Disorder? Psychol Services. 2020; 17(1): 102-109.
24. Ferrara P, Franceschini G, Corsello G. Gambling disorder in adolescents: what do we know about this social problem and its consequences? Italian J Pediat. 2018; 44(1): 146. https://doi.org/10.1186/s13052-018-0592-8

25. St-Pierre R, Derevensky JL. Youth Gambling Behavior: Novel Approaches to Prevention and Intervention. Curr Addict Rep. 2016; 3: 157-165. https://doi.org/10.1007/s40429-016-0104-0

26. Rowicka M. Uzależnienia behawioralne. Profilaktyka i terapia. Warszawa: Fundacja Praesterno. 2015.

27. Banaszkiewicz E, Wojewódzka B. Hazard problemowy. Edukacja i leczenie w warunkach klinicznych [Problem gambling. Education and treatment in clinical conditions]. Warsaw; 2013.

28. Wysocka E. Wschodząca dorosłość a tożsamość młodego pokolenia - współczesne zagrożenia dla kształtowania tożsamości. Analiza teoretyczna i empiryczne egzemplifikacje. [EMERGING ADULTHOOD VERSUS THE IDENTITY OF A YOUNG GENERATIONCONTEMPORARY THREATS TO SHAPING THE IDENTITY. A THEORETICAL ANALYSIS AND EMPIRICAL EXEMPLIFICATION]. Gdynia: Akademia Marynarki Wojennej. 2013.

29. Augustynowicz W, Palacz-Chrisidis A, Wiechetek M, Niewiadomska I, Fel S, Chwaszcz J, Bartczuk RP. Sąsiedzki kapitał społeczny a używanie substancji psychoaktywnych przez młodzież [NEIGHBOURHOOD SOCIAL CAPITAL AND USE OF PSYCHOACTIVE SUBSTANCES BY ADOLESCENTS]. Roczniki nauk społecznych. 2015; 7(43).

30. Potembska E, Pawłowska B, Szymańska J. Psychopathological symptoms in individuals at risk of Internet addiction in the context of selected demographic factors. Ann Agric Environ Med. 2019; 26(1): 33-38.

31. Kałużny R. Aktywność pozalekcyjna i pozaszkolna uczniów gimnazjów - zagospodarowanie czasu wolnego [Extracurricular and extraschool activity of midle school students - the use of leisure time. Prz Pedagogiczny. 2018; 2: 231-244.

32. King DL, Delfabbro PH. The cognitive psychology of Internet gaming disorder. Clin Psychol Rev. 2014; 34: 298-308.

33. Williams RJ, West BL, Simpson RI. Prevention of Problem Gambling: A Comprehensive Review of the Evidence, and Identified Best Practices. Report prepared for the Ontario Problem Gambling Research Centre and the Ontario Ministry of Health and Long Term Care. 2012; 10.

34. Jarczyńska J. Zaangażowanie w hazard młodzieży gimnazjalnej i ponadgimnazjalnej. Diagnoza zjawiska i jego wybranych uwarunkowań. Bydgoszcz: Wydawnictwo Uniwersytetu Kazimierza Wielkiego. 2016.

35. Corbin WR, Cronce JM. Effects of alcohol, initial gambling outcomes, impulsivity, and gambling cognitions on gambling behavior using a video poker task. Exp Clin Psychopharmacol. 2017; 25(3): 175-185.

36. Iliceto P, D’Antuono L, Bowden-Jones H, Giovani E, Giacolini T, Candilera G, Sabatello U, Jaak Panksepp J. Brain Emotion Systems, Personality, Hopelessness, Self/Other Perception, and Gambling Cognition: A Structural Equation Model. J Gambling Studies. 2016; 32(1): 157-169.

37. Rash CL, McGrath DS. Self-Generated Motives for Not Gambling Among Young Adult Non-gamblers. J Gambling Studies. 2017; 33(3): p. $825-839$.

38. Ogińska-Bulik N. Uzależnienie od czynności. Mit czy rzeczywistość? [Behavioural addiction. A myth or reality?] Warsaw: Delf. 2010.

39. Raylu N, Oei T. Pathological gambling: A comprehensive review. Clin Psychol Rev. 2002; 22: 1009-1066.

40. Zygo M, Pawłowska B, Potembska E, Dreher P, Kapka-Skrzypczak L. Prevalence and selected risk factors of suicidal ideation, suicidal tendencies and suicide attempts in young people aged 13-19 years. Ann Agric Environ Med. 2019; 26(2): 329-336.

41. Lejoyeux M, Mc Loughlin M, Ades I. Epidemiology of behavioral dependence: Literature review and results of original studies. European Psychiatry. 2000; 15: 169-173.

42. Lelonek-Kuleta B. Uzależnienia behawioralne na tle współczesnej wiedzy o uzależnieniach. [Behavioral addictions on the background of contemporary knowledge about dependences]. Studia Społeczne. 2015; 12(1): 97-103.

43. Clark C, Nower L, Walker DM. The relationship of ADHD symptoms to gambling behaviour in the USA: results from the National Longitudinal Study of Adolescent Health. Int Gambling Stud. 2013; 13(1): 37.

44. Livingstone S, Palmer T. Identifying vulnerable children online and what strategies can help them. UK Safer Internet Centre, London, UK; 2012 .

45. Ostaszewski K. Monitorowanie zachowań ryzykownych, zachowań nałogowych i problemów zdrowia psychicznego 15-letniej młodzieży. Badania mokotowskie 2004-2016. Warszawa: IPiN. 2017.

46. Jarczyńska J. Evaluation of the Psychometric Properties of SOGS-RA in the Polish Version. J Education Culture and Society. 2016; 2.

47. Stefanovics EA, Potenza MN, Pietrzak RH. Gambling in a National U.S. Veteran Population: Prevalence, Socio-Demographics, and Psychiatric Comborbidities. J Gambl Stud. 2017; 33(4): 1099-1120.

48. Abbott M, Stone CA, Billi R, Yeung K. Gambling and Problem Gambling in Victoria, Australia: Changes over 5 years. J Gambling Stud. 2016; 32(1): 47-78. 